\title{
Zasoby lokalne w planowaniu przestrzennym centrum wsi - studium przypadku Rokietnicy
}

\section{Local resources in spatial planning - case study of Rokietnica}

\section{Bartosz WOJTYRA}

Uniwersytet im. Adama Mickiewicza w Poznaniu Instytut Geografii Społeczno-Ekonomicznej i Gospodarki Przestrzennej ul. B. Krygowskiego 10, 61-680 Poznań bwojtyra@amu.edu.pl

\begin{abstract}
Zarys treści: Celem pracy jest wskazanie znaczenia ziemi jako zasobu lokalnego w rozwoju wsi, zwłaszcza w kontekście zarządzania nią i prowadzonej polityki przestrzennej. Poprzez identyfikację i charakterystykę uwarunkowań oraz samego przebiegu procesu planowania przestrzennego nowego centrum miejscowości Rokietnica, będącej ośrodkiem administracyjnym gminy wiejskiej w powiecie poznańskim, przedstawiono złożoność i wagę strategicznego podejścia do zarządzania przestrzenią na obszarze wiejskim w strefie podmiejskiej. Dzięki przeprowadzonej analizie procesu kształtowania nowej przestrzeni centrum wsi przedstawiono cele wdrożenia, a także czynniki sprzyjające oraz bariery napotykane podczas realizacji projektu. Jednocześnie w pracy wskazano dobre praktyki w zarządzaniu zasobami lokalnymi i polityce przestrzennej gminy wiejskiej.

Do podjęcia badań w oparciu o casus Rokietnicy skłoniło charakterystyczne położenie gminy i w związku z tym zmiana charakteru analizowanej wsi oraz świadome i kompleksowe podejście do planowania przestrzennego przez władze samorządowe. Warta odnotowania jest rozbudowana współpraca na linii: mieszkańcy - władze lokalne - przedstawiciele środowiska naukowego - urbaniści/architekci, która pojawiła się podczas opracowywania koncepcji zagospodarowania przestrzeni, a także zastosowanie innowacyjnych technik konsultacji społecznych, prezentacji założeń projektowych oraz skala przedsięwzięcia i uwarunkowania procesu.
\end{abstract}

Słowa kluczowe: zasoby lokalne, planowanie przestrzenne, Rokietnica, wieś urbanizująca się.

\section{Wstęp}

Współczesna problematyka badań dotycząca geografii wsi związana jest ze zmniejszeniem znaczenia rolnictwa jako źródła dochodów ludności wiejskiej, czego efektem jest m.in. ewolucja nowych funkcji na tych obszarach (Wójcik 2011). Tego typu przemiany szczególnie dotyczą terenów wiejskich leżących w bezpośrednim sąsiedztwie dużych ośrodków miejskich i ich aglomeracji, a więc w tzw. strefie podmiejskiej (m.in. Kołodziejczak 2008; Falkowski 2009; Staszewska 2013). Według nomenklatury, która pojawia się u J. Wilkina (2007, za: Rural... 1997) tereny te są kategoryzowane jako zintegrowane obszary wiejskie. Zgodnie z definicją wykazują one silne funkcjonalne powiązanie z miastami, a ich cechą charakterystyczną jest wzrost liczby mieszkańców w wyniku migracji ludności z miast. 
Zjawisko to jest nieodłącznym elementem i skutkiem procesu suburbanizacji. Rezultatem przekształceń jest zmiana struktur przestrzennych (np. zagęszczanie i wzrost intensywności zabudowy) oraz stopniowe wypełnianie się tkanki ruralistycznej zabudową niezwiązaną z produkcją rolniczą (wzrost znaczenia terenów mieszkaniowych i usługowych), a więc jej urbanizacja.

Wspomniane procesy mają często przebieg niekontrolowany, czego efektem jest chaotyczny rozwój zabudowy. Wsie tracą wiejski charakter, ale nie zyskują też jednoznacznie miejskiego. Stają się mozaikowatą hybrydą bez wyraźnie zarysowanej koncepcji, zbitką osiedli mieszkaniowych (o różnej intensywności bez odpowiednio zaplanowanej infrastruktury technicznej) i terenów o funkcjach przemysłowych, rolniczych czy obszarów o wysokich walorach przyrodniczych. Ziemia staje się ważnym elementem gry rynkowej, a przecież stanowi ona jeden z podstawowych zasobów lokalnych, na bazie którego powinno się budować zrównoważony rozwój danej jednostki terytorialnej, tak aby służyła podniesieniu jakości życia zarówno obecnym, jak i przyszłym pokoleniom. Zarządzanie nią powinno odbywać się z poszanowaniem zasad planowania przestrzennego, a przede wszystkim z uwzględnieniem rozwoju zrównoważonego i ładu przestrzennego (Parysek 2006; Ustawa... 2003), zwłaszcza że jest to element przestrzeni, a więc dobra rzadkiego (Domański 2002). Ziemia jest zasobem lokalnym rozumianym jako grunt budowlany i powierzchnia biologicznie czynna, a więc w tym przypadku jest materialnym czynnikiem będącym podstawą rozwoju lokalnego, elementem potencjału wewnętrznego badanego obszaru, często decydującym o jego powodzeniu (Parysek 2001; Bański 2016; Kołodziejczak 2016).

\section{Cel, postepowanie badawcze i zakres pracy}

Głównym celem pracy jest wskazanie znaczenia ziemi jako zasobu lokalnego w rozwoju wsi, zwłaszcza w kontekście zarządzania nią i prowadzonej polityki przestrzennej. Poprzez identyfikację i charakterystykę uwarunkowań oraz samego przebiegu procesu planowania przestrzennego nowego centrum miejscowości Rokietnica przedstawiono złożoność i wagę strategicznego podejścia do zarządzania przestrzenią na obszarze wiejskim w strefie podmiejskiej. Dzięki przeprowadzonej analizie procesu kształtowania nowej przestrzeni centrum wsi, przedstawione zostaną czynniki sprzyjające oraz bariery napotykane podczas jego realizacji, a także cele jego wdrożenia. Jednocześnie w pracy, mając za wzór wspominane studium przypadku, wskazano dobre praktyki w zarządzaniu zasobami lokalnymi w kontekście polityki przestrzennej gminy wiejskiej.

Postępowanie badawcze składało się z następujących etapów:

- analizy dotychczasowych działań samorządu lokalnego w zakresie polityki przestrzennej i planowania przestrzennego centrum gminy Rokietnica, tj. analizy i oceny zapisów studium uwarunkowań i kierunków zagospodarowania przestrzennego w zakresie przedmiotowego obszaru, a także zapoznano się z miejscowymi planami zagospodarowania przestrzennego dla sąsiadujących terenów;

- przeprowadzenia wizji lokalnej terenu wraz z dokumentacją fotograficzną;

- analizy materiałów kartograficznych udostępnionych przez Urząd Gminy Rokietnica oraz dostępnych na stronach internetowych; 
- udziału w otwartych konsultacjach społecznych dotyczących projektu zagospodarowania centrum Rokietnicy oraz posiedzeniu Komisji Rady Gminy Rokietnica, w czasie której obradowano w przedmiotowym zakresie oraz sesji Rady Gminy Rokietnica, na której podjęto decyzję o przystąpieniu do sporządzenia miejscowego planu zagospodarowania przestrzennego (mpzp) dla omawianego obszaru;

- analizy projektu Wielowariantowej analizy i symulacji zagospodarowania przestrzennego centrum Rokietnicy (2015) zawierającego proponowane koncepcje zagospodarowania przestrzennego oraz analizy uwarunkowań autorstwa Biura Projektowego Armageddon z Poznania, sporządzone przy wsparciu pracowników naukowych Zachodniopomorskiego Uniwersytetu Technologicznego w Szczecinie oraz Uniwersytetu Technologiczno-Przyrodniczego w Bydgoszczy;

- analizy wyników ankiety przeprowadzonej wśród mieszkańców Rokietnicy przez Centrum Badań Metropolitalnych UAM w Poznaniu w ramach tworzonego innowacyjnego „Geoportalu wspierającego partycypację społeczną w planowaniu przestrzennym" finansowanego jako projekt badawczy z budżetu Narodowego Centrum Badań i Rozwoju (nr projektu: PBS3/A9/39/2015).

Do podjęcia badań w oparciu o casus Rokietnicy skłoniło charakterystyczne położenie gminy w strefie podmiejskiej aglomeracji poznańskiej i w związku z tym zmiana charakteru analizowanej wsi oraz świadome, kompleksowo zaprojektowane podejście do planowania przestrzennego przez władze samorządowe. Warte odnotowania jest również pojawienia się w ramach opracowywania koncepcji zagospodarowania przestrzeni rozbudowanej współpracy na linii: mieszkańcy - władze lokalne - przedstawiciele środowiska naukowego - urbaniści/architekci, a także zastosowanie innowacyjnych technik konsultacji społecznych, prezentacji założeń projektowych oraz skala przedsięwzięcia i uwarunkowania procesu.

Teren rozpatrywany jako studium przypadku znajduje się w gminie Rokietnica leżącej w północno-zachodniej części powiatu poznańskiego (ryc. 1). Zgodnie z Planem Zagospodarowania Przestrzennego Województwa Wielkopolskiego (2010) została ona zaliczona do Obszaru Funkcjonalnego Miasta Poznania, należy również do Stowarzyszenia Metropolia Poznań. W wielu innych opracowaniach poświęconych delimitacji polskich obszarów metropolitalnych Rokietnica jako bezpośredni sąsiad miasta Poznania jest zaliczana do tzw. aglomeracji poznańskiej (m.in. Parysek 2008; Strategia... 2013; Studium... 2013; Koncepcja... 2014).

Powierzchnia gminy wynosi $79,31 \mathrm{~km}^{2}$, sama miejscowość Rokietnica zajmuje około $6,77 \mathrm{~km}^{2}$, natomiast analizowany teren to nieco ponad $0,12 \mathrm{~km}^{2}$ (12 ha).

Obszar będący studium przypadku jest w zdecydowanej części niezagospodarowany. Znajduje się w ścisłym, geometrycznym centrum wsi, pomiędzy ważnymi szlakami komunikacyjnymi. W pobliżu znajduje się dworzec kolejowy, obiekty użyteczności publicznej, takie jak szkoła, kościół, hala sportowa (ryc. 2). 


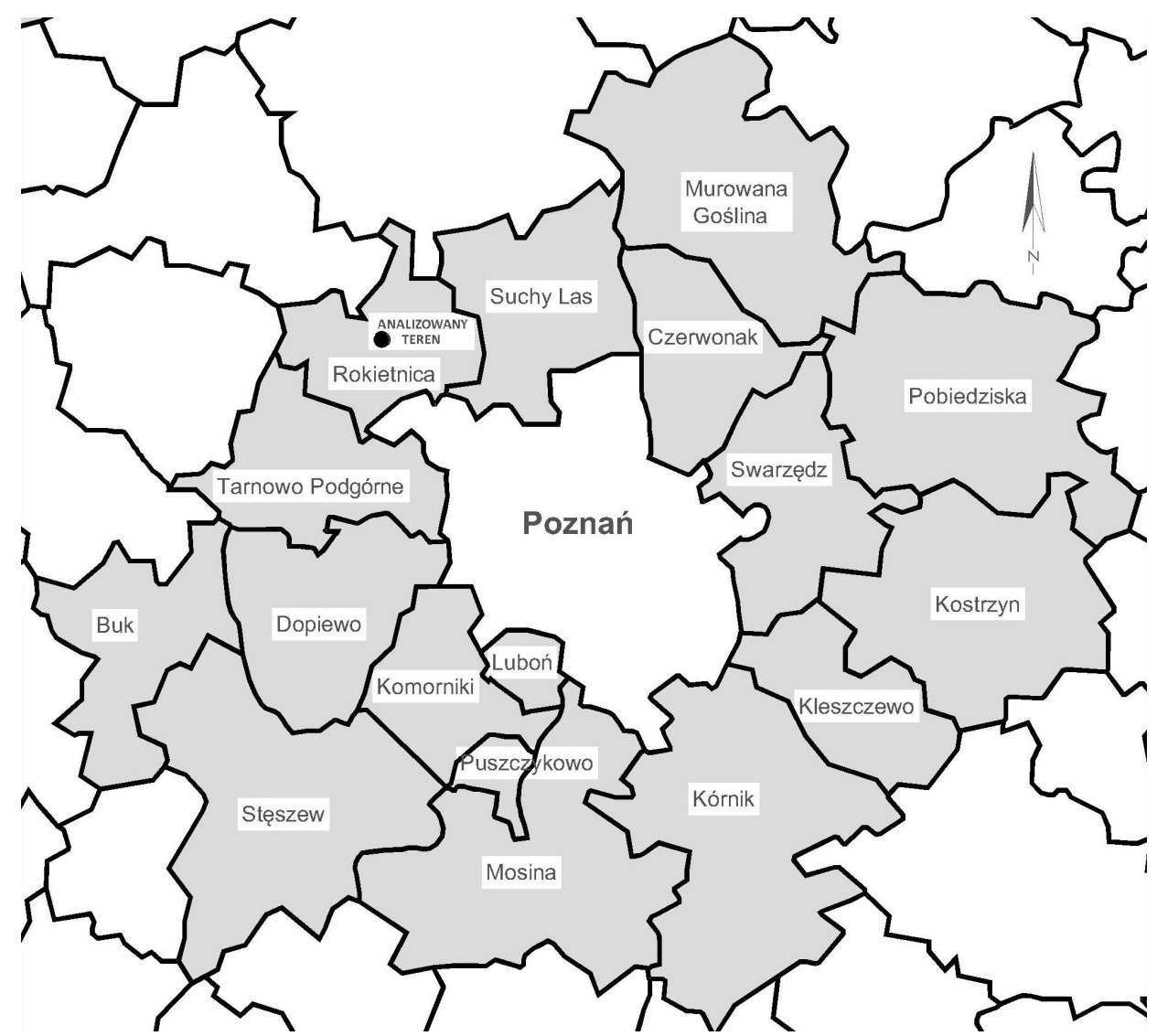

Ryc. 1. Położenie gminy Rokietnica i analizowanego terenu Źródło: opracowanie własne.

Location of the Rokietnica commune and area under analysis Source: own elaboration. 

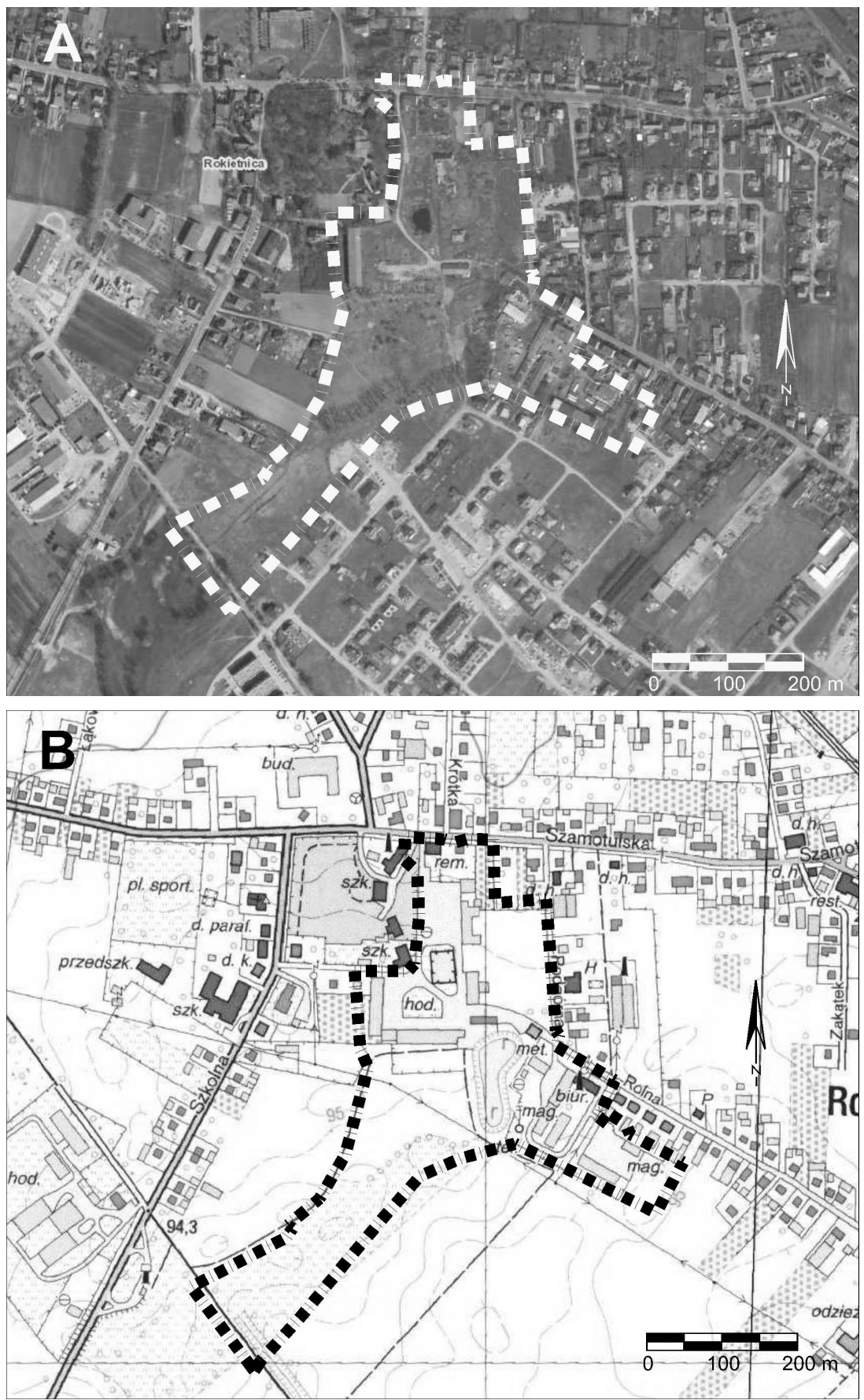

Ryc. 2. Położenie zagospodarowywanego centrum Rokietnicy na ortofotomapie (A) i mapie topograficznej (B) Źródło: opracowanie Biuro Projektowe Armageddon.

Location of the developed Rokietnica centre on an orthophotomap (A) and a topographic map (B)

Source: own study of Armageddon Biuro Projektowe. 


\section{Kierunki rozwoju przestrzennego w zintegrowanych obszarach wiejskich a zasoby lokalne}

Znaczące w skali gminy wsie położone w obrębie dużych miast zmieniają swój charakter i tracą wiele z wiejskiego charakteru. Wsie podmiejskie są szczególnym przypadkiem obszarów wiejskich, na których stopniowo zanika funkcja rolnicza. Bliskość miasta, a więc większego rynku pracy i udogodnień, jest przyczyną znaczących przemian w zagospodarowaniu przestrzennym (Liszewski 1985). Podstawowe przekształcenia ziemi na obszarach wiejskich znajdujących się w strefie podmiejskiej dotyczą struktury jej użytkowania, ale także m.in. skali, architektury i funkcji zabudowy, wielkości działek, gęstości sieci dróg (Kacprzak i Staszewska 2008). J. Bański (2008) stwierdza, że tereny te nie powinny być wprost klasyfikowane jako obszary wiejskie, a odrębnie jako strefa podmiejska, a ciągłość pomiędzy tym, co charakteryzujemy jako miasto, a tym co nazywamy jednoznacznie wsią, wskazuje nazywać terminem „kontinuum miejsko-wiejskie”.

Zgodnie z teorią wielofunkcyjnego rozwoju centra ośrodków wiejskich wypełniają się funkcjami pozarolniczymi, w tym przede wszystkim drobnymi usługami i rzemiosłem (Kostrowicki 1976; Kłodziński 1996; Rosner 2001). Idea ta może być rozpatrywana w płaszczyźnie funkcjonalo-przestrzennej, ponieważ wprowadzane nowe funkcje nieuchronnie wiążą się ze zmianą sposobu zagospodarowania (Czarnecki 2005). Efektem procesu jest kształtowanie przestrzeni publicznych typowych dla małych miasteczek czy dzielnic dużych miast.

Stopniowe przekształcanie się wsi w miasto nazywamy procesem jej urbanizacji. Według D. Sokołowskiego (2005, za: Staszewska 2013) można go rozpatrywać w dwóch ujęciach. Omawiany przypadek dotyczy podejścia drugiego, ogólniejszego, czyli sensu largo. W tym ujęciu urbanizacja nie prowadzi do pełnej „miejskości” danej wsi, a jest jedynie konsekwencją odejścia od rolniczych źródeł utrzymania ludności. Rezultaty widoczne są w sferze społecznej (upowszechnienie się miejskiego stylu życia), ekonomicznej (pozarolnicze źródła dochodu), demograficznej (zmiana struktury ludności), morfologicznej (zabudowa niewiejska) i infrastrukturalno-technicznej (wyposażenie osiedli).

Co ważne z punktu widzenia realizowanej pracy, urbanizacja wsi wymaga harmonijnego wkomponowania w jej przestrzeń punktu centralnego, wykształcenia miejsca, które odgrywałoby rolę rynku, placu, na którym organizowałoby się życie społeczne (Czernik i Zimnicka 2007). Pozwoli to uniknąć sytuacji, w której wieś podmiejska staje się zbiorem odrębnych osiedli mieszkaniowych stanowiących enklawy i negatywnie wpływających na tożsamość miejsca. Według K. Heffnera (2015) społeczeństwo staje się coraz bardziej wymagające w stosunku do miejsca zamieszkania. Ponadto stwierdza on, że w niedalekiej przyszłości obszary wiejskie będą rozwijały formy zagospodarowania przyczyniające się do wzrostu gospodarczego, ale także podniesienia atrakcyjności wsi jako miejsca zamieszkania.

Omawiany w pracy projekt nosi w sobie znamiona procesu odnowy wsi, który według W. Idziaka i R. Wilczyńskiego (2013, s. 4) stanowi „kierunek rozwoju obszarów wiejskich łączący w sobie szacunek dla tradycji z potrzebą szukania miejsca dla wsi w zmieniającym się świecie. Odnowa wsi jest procesem, stałym dopasowywaniem się do społecznych i gospodarczych, wewnętrznych i zewnętrznych zmian. Prowadzić powinna do całościowego kształtowania warunków życia mieszkańców wsi.". Ponadto, jak zaznaczają autorzy, zakres odnowy wsi jest ujmowany m.in. w obszarze wizerunkowo-budowlano-przestrzennym 
(budownictwo, mieszkalnictwo, obraz wsi, ruch uliczny, komunikacja, infrastruktura, publiczne tereny zielone, kształtowanie krajobrazu).

Przykłady realizacji projektów będących wyrazem dobrych praktyk w zagospodarowaniu przestrzeni wiejskiej przedstawia w swojej pracy m.in. J. Krzyżaniak (2012). Prezentując prace laureatów konkursu „Przyjazna wies”, zwraca ona uwagę na konieczność podejmowania działań służących poprawie w równym stopniu stanu infrastruktury technicznej oraz społecznej. Zauważa ponadto, że wieś staje się zarówno pożądanym miejscem zamieszkania, jak i pracy oraz wypoczynku. Dobre projekty zatem łączą w sobie zaspokajanie tych podstawowych potrzeb ludzkich. Na terenie wsi, zwłaszcza podmiejskich, powinny znajdować się przestrzenie publiczne służące mieszkańcom i spełniające funkcje inne niż mieszkaniowe.

Należy w tym miejscu zwrócić uwagę, że rozwój przestrzenny obszarów wiejskich w strefie podmiejskiej napotyka również istotne bariery (które zostaną przedstawione w dalszej części studium przypadku), czasami przeważające nad zainteresowaniem inwestycyjnym, wynikające z niekontrolowanego zjawiska suburbanizacji. Należą do nich:

- bariery demograficzno-społeczne - brak integracji społeczeństwa rdzennego i napływowego oraz niepokojąca sytuacja demograficzna związana z trendami ogólnopolskimi;

- bariery infrastrukturalne - infrastruktura techniczna „nienadążająca” za rozwojem zabudowy;

- bariery przyrodnicze - obecność obszarów chronionych z zakazem zabudowy, wysoka bonitacja gleb;

- bariery prawne - chaotyczność i niespójność polskiego systemu planowania przestrzennego;

- gospodarcze oraz ekonomiczno-finansowe - rozdrobnienie gospodarstw, niska renta położenia, poziom dofinansowania gmin itd.;

- administracyjne i przestrzenne - prowadzona lokalna polityka przestrzenna (Staszewska 2009).

Zadaniem władz samorządowych jest dbać, aby zmiana wywołana suburbanizacją zachodziła w sposób uporządkowany i niewywołujący konfliktów przestrzennych. Do tego niezbędna jest świadomość zachodzących procesów oraz zrozumienie znaczenia zasobów lokalnych.

\section{Uwarunkowania planowania przestrzennego centrum Rokietnicy}

Rokietnica jest intensywnie rozwijającą się gminą. Świadczy o tym regularny przyrost liczby ludności czy prowadzone na jej terenie rozliczne inwestycje gospodarcze, infrastrukturalne i mieszkaniowe. Położenie gminy w bezpośrednim sąsiedztwie Poznania niejako wymusza na tym terenie jego intensywny rozwój przestrzenny i gospodarczy, a co za tym idzie konieczność dostosowania się do wymagań narzucanych przez otoczenie. Zmiany mają charakter ilościowy: więcej mieszkańców, więcej zabudowy, więcej inwestycji. Rosnąca liczba użytkowników przestrzeni powoduje, że konieczne są również zmiany jakościowe.

Na koniec 2016 r. w gminie Rokietnica zamieszkiwało 16018 osób, natomiast w miejscowości Rokietnica, która pełni funkcję centrum administracyjno-gospodarczego gminy, 
około 5000 mieszkańców. Od lat 90. XX w. notowany był sukcesywny wzrost liczby ludności zarówno gminy, jak i samej miejscowości Rokietnica. Od początku XXI w. wartość ta podwoiła się, co jest wynikiem migracji zewnętrznych wywołanych m.in. nasilonym ruchem inwestycyjnym w aglomeracji poznańskiej. Rokietnica staje się swoistą „sypialnią aglomeracyjną" Poznania (Barełkowski 2010). A. Rosner (2012, s. 57), tworząc typologię obszarów wiejskich zmniejszających i zwiększających zaludnienie, zakwalifikował gminę Rokietnica do typu 4, tj. koncentrującego ludność wiejską. Charakteryzuje się ona spełnianiem jednocześnie trzech kryteriów: „przyrostu liczby ludności w okresie 2002-2008 o co najmniej 20\%, niskiego udziału ludności w wieku poprodukcyjnym (mniej niż 14\%) oraz dodatniego salda migracji wewnętrznych (o skali co najmniej 2 osoby na 1 tys. mieszkańców) w skali roku". Wśród przyczyn zjawiska suburbanizacji w aglomeracji poznańskiej, czego skutkiem jest zasiedlanie Rokietnicy, upatruje się m.in. spadek znaczenia funkcji mieszkaniowej centrum Poznania powodujący odpływ ludności z tego obszaru (Staszewska 2008).

Wzrost gospodarczy powinien iść w parze z racjonalną gospodarką przestrzenną, tak aby wzmacnianie niezależności ekonomicznej nie odbyło się kosztem nieracjonalnego wykorzystania i degradacji zasobów lokalnych. Otwarcie gminy na osiedlanie się nowych mieszkańców, często związanych wcześniej z ośrodkiem aglomeracyjnym, skutkuje potrzebą wytworzenia przestrzeni, która byłaby miejscem jednocześnie integracji społeczności lokalnej oraz napływowej, a także spełniała odrębnie oczekiwania jednych i drugich (Czernik i Zimnicka 2007). Zagospodarowanie centrum Rokietnicy ma dla tej kwestii kluczowe znaczenie. Przestrzeń omawianej miejscowości nie ma silnie wykształconego miejsca, które ogniskowałoby w kontekście przestrzennym życie społeczne oraz gospodarcze i stanowiłoby o nowym współczesnym charakterze tej wsi (Rokickie Wiadomości... 2015). Budowa kolejnego osiedla ekstensywnego, oderwanego od struktury wsi nie stanowiłaby w tym przypadku panaceum, wręcz przeciwnie mogłaby prowadzić do pogłębiania się barier wśród rosnącej populacji Rokietnicy.

Głównym celem przyświecającym władzom w trakcie prac nad tworzeniem nowego centrum Rokietnicy było wykorzystanie niezagospodarowanych zasobów ziemi o wartościowej lokalizacji poprzez wykształcenie przestrzeni publicznej będącej wizytówką gminy, która zintegrowałaby mieszkańców, pozwoliłaby na stworzenie miejsca spotkań czy rozwoju nowych funkcji gospodarczych, przede wszystkim drobnej przedsiębiorczości. Ponadto realizacja założeń jest dążeniem do zmiany charakteru samej wsi, jej wyraźnej urbanizacji poprzez uzupełnienie tkanki ruralistycznej zabudową o cechach typowo małomiejskich. Budowa centrum ma być racjonalną odpowiedzią na zaistniałe trendy. Przygotowaną i przemyślaną reakcją, którą umożliwi częściową kontrolę nad galopującą suburbanizacją. Dodatkowo realizacja koncepcji zaktywizuje obszar zaniedbany, wymagający rewitalizacji, dzięki bezpośredniemu połączeniu w jego obrębie kilku ważnych szlaków komunikacyjnych. Kompleksowe zagospodarowanie przy odpowiednich nakładach będzie skutkować rozwojem infrastruktury, cennych terenów zieleni czy placów. Wreszcie budowa centrum opartego o intensywne funkcje mieszkaniowo-usługowe pozwoliłaby na zwiększenie atrakcyjności samej miejscowości - ośrodka gminnego i w rezultacie przyjęcie znacznej grupy nowych mieszkańców, również dzięki nowo powstałym miejscom pracy. Pośrednim skutkiem realizacji samego miejscowego planu zagospodarowania przestrzennego będzie wzrost wartości gruntów, w tej chwili nieużytkowanych, a w przyszłości stanowiących obszar silnie, ale bezkonflikto- 
wo zaplanowany i zagospodarowany, o korzystnej lokalizacji, co jednocześnie pozwoli uniknąć powstania rozproszonej, chaotycznej zabudowy, będącej efektem wydawanych niespójnych decyzji o warunkach zabudowy i zagospodarowania terenu w pozostałych częściach miejscowości.

Prace nad wyprzedzającą procedurę uchwalenia mpzp koncepcją zagospodarowania przestrzennego centrum Rokietnicy rozpoczęto w połowie 2015 r. Należy jednak zaznaczyć, że idea realizacji tego projektu powstała znacznie wcześniej. Możliwość kontynuacji wstępnych założeń była możliwa przede wszystkim dzięki temu, że gmina jest zarządzana od 2006 r. przez tę samą osobę, co gwarantuje polityczną stabilność i pozytywnie wpływa na procesy inwestycyjne. Tylko taki sposób, poprzez zamierzone działanie w perspektywie wieloletniej, daje możliwość realizacji strategicznego planowania przestrzennego.

Istotnym punktem procesu projektowania centrum Rokietnicy było przyjęcie Studium uwarunkowań i kierunków zagospodarowania przestrzennego gminy Rokietnica w 2011 r. Analizowany teren został zakwalifikowany w dokumencie określającym politykę przestrzenną gminy jako tzw. Strategiczna Rezerwa Inwestycyjna, czyli „obszar, na którym decyzja rozwoju przestrzennego nie jest skutkiem przyjęcia rozwiązań zawartych w Studium, lecz strategicznej decyzji podejmowanej przez Radę Gminy w chwili realizacji procedury miejscowego planu zagospodarowania przestrzennego z zastrzeżeniem, że w wybranych przypadkach decyzja ta podyktowana jest wyborem najbardziej optymalnego sposobu zagospodarowania, jaki dla strategicznie ważnych dla gminy terenach się ujawnia w danym momencie" (ryc. 3).

Takie rozwiązanie w tworzeniu dokumentu Studium i w zarządzaniu lokalnymi zasobami, dzięki któremu zachowane zostają do dyspozycji gminy obszary mające dla rozwoju przestrzennego znaczenie kluczowe, na których planowanie przestrzenne może mieć znaczący wpływ na życie społeczno-gospodarcze danej jednostki samorządu terytorialnego, należy ocenić jako innowacyjne. Teren Strategicznej Rezerwy Inwestycyjnej ma za zadanie zapewnić gminie maksymalizację potencjału rozwojowego poprzez intensywne wykorzystanie terenów cennych pozostających niezagospodarowanymi (lub zagospodarowywanymi w sposób niewspierający rozwoju), dla których optymalnym rozwiązaniem jest zachowanie możliwości podjęcia ostatecznej decyzji o kierunku i kształcie zagospodarowania wynikającej z diagnozy aktualnej sytuacji społeczno-gospodarczej i przestrzennej w przyszłości (Studium... 2011).

Przyszłe zagospodarowanie badanego obszaru uregulowano w Studium, proponując scenariusze oparte na konkretnych profilach rozwoju wsi w przyszłości. Zasugerowano opcjonalne możliwe rozwiązania planistyczne, które wprowadzają relatywnie ścisłe zapisy dotyczące przyszłych kierunków i parametrów zabudowy. Analizowany teren rozpatrywany był w trzech częściach oznaczonych na rysunku części B Studium - Kierunki zagospodarowania przestrzennego jako R-01XS, R-02XS, R-03XS (ryc. 3). Dla każdej z nich zaproponowano alternatywne wersje zagospodarowania. Oscylowały one jednak wokół kształtowania w różnych kompilacjach nowego centrum Rokietnicy, z uwzględnieniem w projekcie otwartej przestrzeni publicznej w postaci placu jako najsilniejszego elementu kompozycji urbanistycznej oraz zwartej zabudowy mieszkaniowej z usługami, zazwyczaj w parterach. Dodatkowo przestrzeń miałaby być wypełniana terenami zieleni. Szczegółowość uchwalonego Studium pozwalała mieć pewność, że tworzony w przyszłości miejscowy plan zagospodarowania przestrzennego będzie odzwierciedlał plany władz sa- 
morządowych w związku z tworzeniem przestrzeni publicznej w sercu wsi. Prowadzone prace nad koncepcją rozwoju stały się udziałem ośrodków badawczych wspomagających proces w kwestiach projektowych, planistycznych, również na etapie rozbudowanych konsultacji społecznych. Warto zaznaczyć, że teren jest udziałem niewielu właścicieli (dokładnie trzech, a podział własnościowy posłużył m.in. do wyznaczenia granic trzech obszarów w ramach SRI), co znacznie ułatwia proces prowadzenia negocjacji w sprawie przyjęcia proponowanych założeń projektowych.

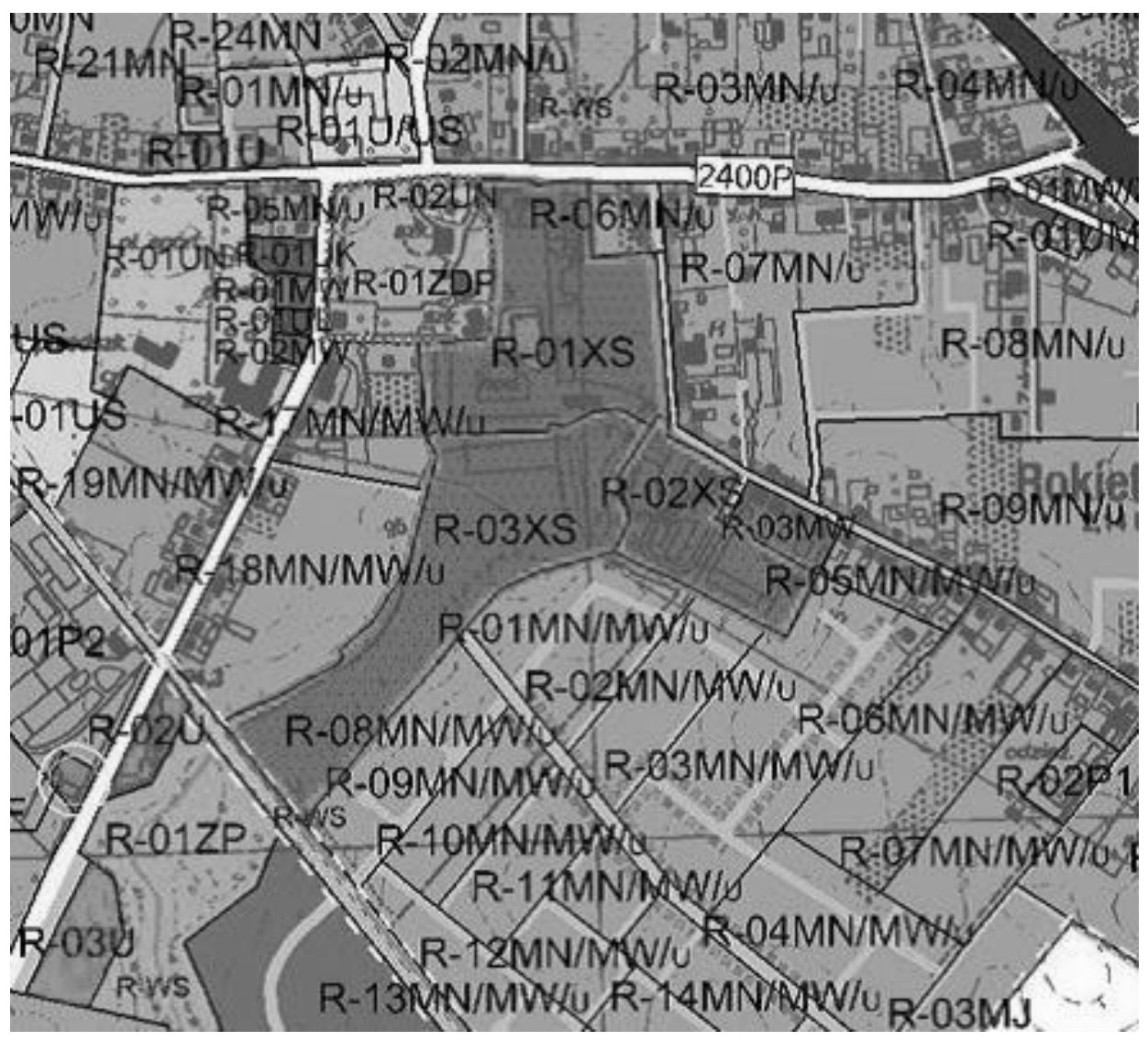

Ryc. 3. Analizowany teren oznaczony jako Strategiczne Rezerwy Inwestycyjne (SRI) w SUiKZP gminy Rokietnica, 2011

Źródło: Studium uwarunkowań i kierunków zagospodarowania przestrzennego Gminy Rokietnica, 2011; materiały Biura Projektowego Armageddon i Urzędu Gminy Rokietnica.

The area under analysis marked as a Strategic Investment Reserve (SIR) in Study of conditions and directions of spatial management of the Rokietnica Commune, 2011

Source: The document: Study of conditions and directions of spatial management of Rokietnica Commune, 2011; own documents of Armageddon Biuro Projektowe and the Rokietnica Commune Office.

Pomimo wielu zalet wybrany obszar ujawnił również liczne problemy stanowiące bariery dla tworzenia projektowanego centrum. Po pierwsze, już na etapie wstępnej inwentaryzacji urbanistycznej przeprowadzonej na potrzeby przygotowania projektu miejscowego planu zagospodarowania przestrzennego stwierdzono niedogodności związane 
z warunkami wodnogruntowymi, które rzutują na możliwość posadowienia budynków. Wykonane na zlecenie gminy badania geotechniczne wskazały tereny, na których należy unikać lokalizowania kubaturowych obiektów budowlanych. Proponuje się wykorzystanie ich zgodne z pierwotną funkcją, jako układ melioracyjny, stanowiący jednocześnie strefę rekreacyjną. Spowodowało to konieczność ponownego przemyślenia koncepcji zagospodarowania i jej częściowego przeprojektowania. Badanie geotechniczne na potrzeby mpzp to bardzo rzadka, ale godna pochwały praktyka samorządu, która wskazuje na profesjonalne podejście do procesu planistycznego i wagę przedsięwzięcia.

Jednym z najczęściej występujących problemów przy okazji podjęcia prac nad tego typu procesem jest niełatwa współpraca z osobami, dla których przedmiotowy grunt stanowi własność, a więc sytuacja, w której stawia się po przeciwnych stronach interesy jednostki i ogółu. Również w omawianym studium przypadku właściciele gruntów przedstawili własne koncepcje rozwoju tego obszaru, zupełnie jednak odmienne od proponowanych przez samorząd. Zakładały one zazwyczaj wysoką intensywność zabudowy oraz profil zagospodarowania niewymagający nakładów, nastawiony na szybki i wysoki zysk z inwestycji (np. zespół garaży). Niezwykle trudno jest wówczas oczekiwać wśród właścicieli akceptacji dla projektu, który ma przede wszystkim nieść niewymierne korzyści dla całej lokalnej społeczności.

Następną barierą było przyjęcie koncepcji przez silnie zróżnicowane społeczeństwo. Z punktu widzenia polityki przestrzennej gminy budowa nowego centrum jest decyzją trudną, odpowiedzialną i mało popularną, jak w przypadku większości planów strategicznych ze względu na przyszły efekt, który nie jest namacalny, a który w założeniu będzie realizowany w perspektywie 10-20 lat. Niezwykle istotna jest sama chęć władz do podjęcia jawnej dyskusji nad kształtem przestrzeni, co zdecydowanie powinno ułatwić zrozumienie planów gminy. Jednak mimo zaawansowanego stopnia konsultacji społecznych, oswajania z projektem, edukacji i informowania mieszkańców na każdym etapie procedowania, trudno uniknąć otwartych protestów, zwłaszcza osób zaangażowanych bezpośrednio, a więc właścicieli przedmiotowych gruntów. Społeczność i w tym przypadku podzielona została na dwie grupy. Pierwszą stanowią rdzenni mieszkańcy, zazwyczaj osoby starsze, według których Rokietnica w dalszym ciągu powinna mieć typowo wiejski charakter i którzy nie życzą sobie stopniowego przekształcania w miasto, tym samym nie zauważając postępujących trendów. Według Raportu z konsultacji społecznych na temat kierunków zagospodarowania przestrzennego centrum miejscowości Rokietnica (2016) ponad 80\% respondentów biorących udział w przeprowadzonej przez Centrum Badań Metropolitalnych ankiecie opowiedziało się za realizacją zabudowy nie wyższej niż 3 kondygnacje (w tym za niższą niż 3 prawie 39\% ankietowanych). Tylko 11\% respondentów (44 na 399 wypowiedzi) opowiedziało się za wysoką intensywnością zabudowy w centrum Rokietnicy (wskaźnik powyżej 40\% powierzchni całkowitej zabudowy). Druga grupa o odmiennych poglądach, to ludność napływowa, osoby młodsze, które większość dnia spędzają w mieście z uwagi na miejsce pracy. Dla nich niezwykle cenne jest wytworzenie przestrzeni choćby do spędzania wolnego czasu. Ostatecznym konsensusem stało się wykreowanie nowego centrum Rokietnicy, służącego obecnym mieszkańcom poprzez stworzenie dostępnej przestrzeni publicznej wraz z rozwojem terenów usługowych oraz zabudowy mieszkaniowej o intensywności niewykraczającej poza znane w miejscowości osiedla. W przypadku tak dużej inwestycji niezwykle ważne jest, aby tworzone zagospodarowanie nie wywołało efektu alienacji ludności napływo- 
wej i podziału społeczeństwa w przyszłości na „my” (mieszkańcy rdzenni) i „wy” (napływowi). Projektanci dostosowali w kolejnym etapie projekt do zebranych wyników „geoankiety".

Wśród trudności napotykanych w procesie zagospodarowania zasobu lokalnego, jakim jest ziemia, zawsze występują wysokie koszty projektu. Ponadto zgodnie z obowiązującymi przepisami, na obszarze wiejskim wymagana jest zgoda ministra rolnictwa o przeznaczeniu gruntów rolnych na cele nierolnicze i nieleśne, w przypadku wystąpienia gruntów klasy III i wyższej, co również ma miejsce podczas realizacji tego projektu. Warto również zaznaczyć, że w omawianym studium przypadku istotnym problemem, z punktu widzenia projektowania koncepcji zagospodarowania, była wydana w postępowaniu odwoławczym decyzja o warunkach zabudowy, a następnie pozwolenie na budowę budynku wielorodzinnego w granicach opracowania, co w ostatniej chwili zmusiło projektantów do zastosowania znaczących korekt w projekcie układu kompozycyjnego i transportowego. Jest to tylko kolejny argument potwierdzający patologiczność obecnego systemu planowania przestrzennego w Polsce opartego w dużej mierze na doraźnie wydawanych decyzjach administracyjnych o warunkach zabudowy i zagospodarowania terenu. Tym bardziej zasadne jest promowanie działań zgodnych z dobrymi praktykami w planowaniu przestrzennym, których omawiany projekt jest przykładem.

Zaprezentowane dotychczas przez zespół urbanistów i architektów wstępne trzy alternatywne koncepcje zagospodarowania przestrzeni centrum Rokietnicy skupiają się wokół programu wytworzenia otwartej przestrzeni publicznej z rekreacyjnymi terenami zieleni współgrającej z zabudową mieszkaniową wielorodzinną i usługową o różnych, w zależności od wersji, warunkach i parametrach kształtowania zabudowy, mającą za zadanie wykształcenie nowego charakteru miejscowości i wejścia na wyższy poziomu rozwoju zrównoważonego (Rokickie Wiadomości... 2015; ryc. 7). Wybrana koncepcja zagospodarowania przestrzennego, która posłużyła za podstawę do sporządzenia miejscowego planu zagospodarowania przestrzennego, została przedstawiona radnym gminy w terenie w formie wizualizacji 3D przy użyciu nowatorskiej, jak na potrzeby planowania przestrzennego, technologii Virtual Reality (Samsung Occulus). Ponadto stworzone zostały symulacje chłonności terenu (tzn. ilu użytkowników stałych i czasowych przewiduje projekt dla proponowanej zabudowy), w związku z tym opracowano koncepcje wypełnienia miejsc parkingowych oraz wyliczono zapotrzebowanie na media i inne usługi.

Projekt miejscowego planu zagospodarowania przestrzennego będzie opiniowany i uzgadniany przez właściwe terenowo i ustawowo organy oraz poddany kolejnemu etapowi partycypacji społecznej w 2017 r. („geodyskusja”). Faza przyjęcia koncepcji jest kluczowa dla projektu, ponieważ kompozycja urbanistyczna będzie w przyszłości determinować powodzenie tego miejsca, a więc zainteresowanie inwestorów, realizację obiektów i ich architekturę, jego odbiór estetyczny i utożsamianie się z nim, chęć spędzania tam czasu przez mieszkańców oraz intratność prowadzenia działalności gospodarczej. 


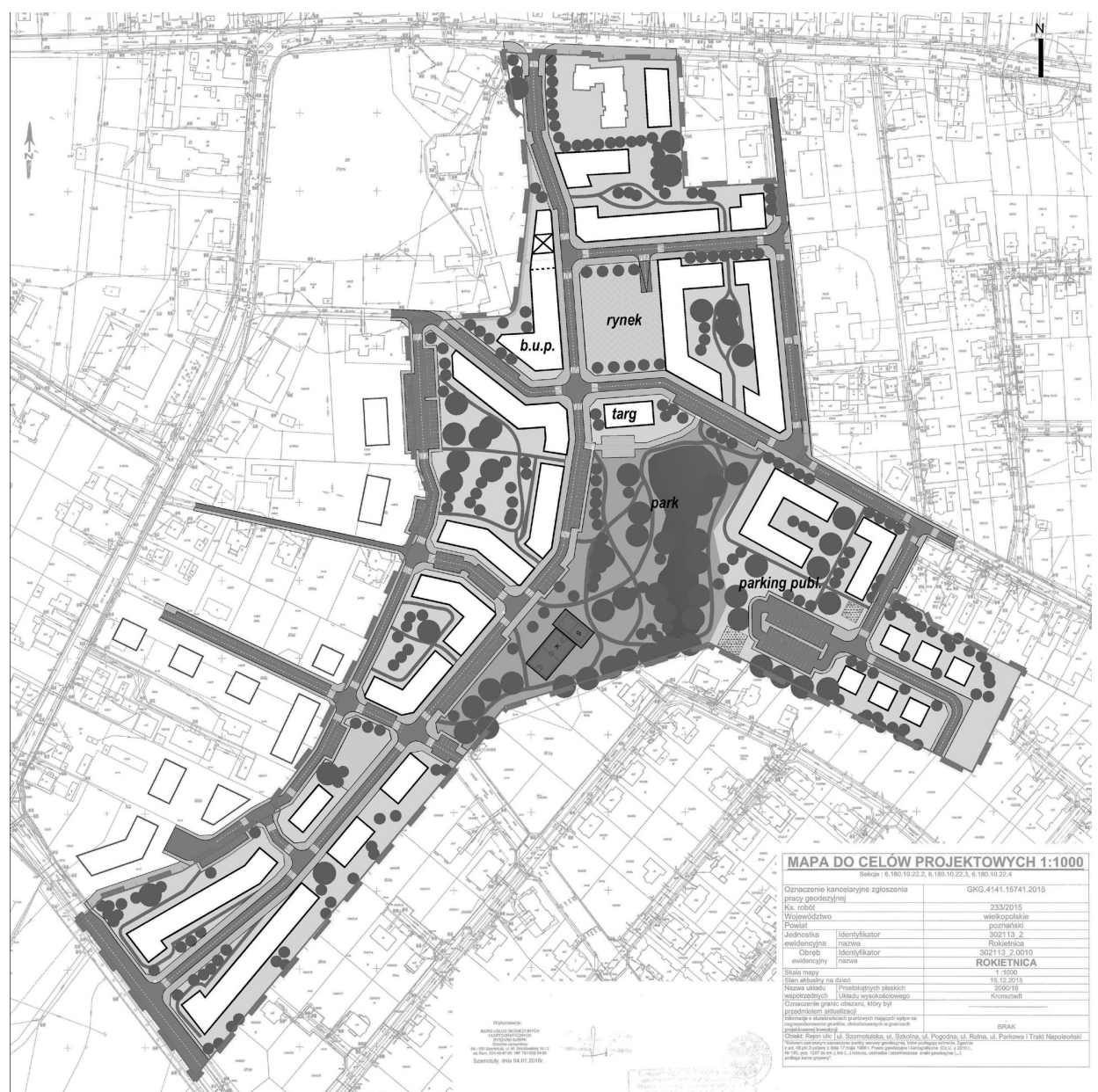

Ryc. 4. Wstępna koncepcja zagospodarowania przestrzennego centrum Rokietnicy Źródło: materiały Biura Projektowego Armageddon.

The preliminary spatial development project of the new Rokietnica centre Source: own study of Armageddon Biuro Projektowe.

\section{Podsumowanie}

Zachodzące w przestrzeni podmiejskiej przemiany obszarów wiejskich są trudne do powstrzymania, dlatego planowanie przestrzenne, zwłaszcza w obszarze metropolitalnym, szczególnie narażonym na negatywne skutki procesu suburbanizacji, wymaga od władz gmin, odpowiedzialnych za politykę przestrzenną, zrozumienia procesów zachodzących w otoczeniu i reagowania z odpowiednim wyprzedzeniem. Świadomość zachodzenia suburbanizacji pozwala na podejmowanie strategicznych decyzji w polityce przestrzennej gminy. Może to powstrzymać proces niekontrolowanej zabudowy, chaosu przestrzennego, trudności komunikacyjnych, zanieczyszczenia środowiska, degradacji krajobrazu, nieracjonalnego wykorzystania zasobów lokalnych, a w wyniku zatracenia 
tożsamości danego miejsca pozwoli na zadbanie o wytworzenie przestrzeni przyjaznej mieszkańcom.

Projekt centrum Rokietnicy jest pozytywnym przykładem strategicznego, długoterminowego i innowacyjnego podejścia do planowania przestrzennego gminy w dużej aglomeracji miejskiej oraz wielopoziomowej współpracy na linii władze - mieszkańcy - ośrodki naukowo-badawcze - urbaniści - architekci. Dzięki rzetelnie i szczegółowo sporządzonemu studium uwarunkowań i kierunków zagospodarowania przestrzennego ma szansę, poprzez wyprzedzająco zaprezentowane alternatywne koncepcje zagospodarowania przestrzennego, a następnie szczegółowy plan miejscowy, zrealizować się wizja wykształcenia przestrzeni publicznej stanowiącej miejsce integracji mieszkańców, w tym ludności autochtonicznej i allochtonicznej, których oczekiwania wobec otoczenia, w którym żyją, mogą się znacząco różnić.

W czasie prac nad koncepcją zagospodarowania nowego centrum Rokietnicy, mimo godnego pochwały strategicznego podejścia władz do zagadnienia przyszłego rozwoju przestrzennego miejscowości, pojawiły się bariery, a wśród nich przede wszystkim niekorzystne uwarunkowania przyrodnicze oraz podzielone głosy społeczeństwa na temat kierunku zagospodarowania oraz warunków i parametrów kształtowania zabudowy przedmiotowego obszaru. Unaocznienie trudności i barier może stanowić źródło cennych wskazówek dla samorządów chcących podjąć podobne zadanie.

Władze samorządowe, chcąc kontrolować procesy zachodzące w strefie podmiejskiej, powinny być w stanie określić i obrać przyszły, czytelny kierunek rozwoju przestrzennego gminy (czy to związany z rolnictwem i utrzymaniem typowo wiejskiego charakteru, czy z rozwojem funkcji typowych dla miast) i zgodnie z nim kształtować spójną politykę przestrzenną. Kierunek ten powinien uwzględniać oczekiwania społeczne, uwarunkowania zewnętrzne, wartość zasobów lokalnych i ich optymalne wykorzystanie. Planowanie przestrzenne w powiązaniu z odpowiedzialną polityką przestrzenną powinno wynikać z przemyślanego podejścia strategicznego, a samo projektowanie urbanistyczne prowadzące do wytworzenia stanu zagospodarowania przestrzennego zgodnego z rozwojem zrównoważonym musi być działaniem kompleksowym, z zadbaniem o szczegóły, zrozumieniem odpowiedzialności i wagi przedsięwzięć, z jasnym przekazem do społeczeństwa o planach, miejscem starcia się i jednoczesnego dojścia do porozumienia różnych środowisk, mających lub mogących mieć wpływ na kształt przestrzeni.

\section{Literatura}

Bański J., 2008, Strefa podmiejska - już nie miasto, jeszcze nie wieś, [w:] A. Jezierska-Thöle, L. Kozłowski (red.), Gospodarka przestrzenna w strefie kontinuum miejsko-wiejskiego w Polsce, Wydawnictwo Naukowe Uniwersytetu Mikołaja Kopernika, Toruń, s. 29-44.

Bański J., 2016, Identyfikacja i wykorzystanie zasobów lokalnych w budowaniu przewagi konkurencyjnej - przykład regionu lubelskiego, Studia Obszarów Wiejskich, 44, s. 7-19.

Barełkowski R., 2010, Suburbia as a battlefield between society, environment and planning strategies, The Sustainable City VI, WIT Transactions on Ecology and the Environment, 129, WIT Press, Southampton, s. 371-382.

Czarnecki A., 2005, Obszary wiejskie, urbanizacja wsi, rozwój wielofunkcyjny, rolnictwo wielofunkcyjne - przeglqqd pojęć, [w:] A. Rosner (red.), Uwarunkowania i kierunki przemian spotecno-gospodarczych na obszarach wiejskich, IRWiR PAN, Warszawa, s. 233-254. 
Czernik L., Zimnicka A., 2007, Vademecum wsi podmiejskiej. Jakość zagospodarowania przestrzennego, Wydawnictwo Hogben, Szczecin.

Domański R., 2006, Gospodarka przestrzenna. Podstawy teoretyczne, Wydawnictwo Naukowe PWN, Warszawa.

Falkowski J., 2009, Przekształcenia funkcjonalno-przestrzenne obszarów wiejskich w strefach podmiejskich obszarów metropolitalnych Polski, Studia Obszarów Wiejskich, 18, s. 49-70.

Heffner K., 2015, Przestrzeń jako uwarunkowanie rozwoju obszarów wiejskich w Polsce, Wieś i Rolnictwo, 2 (167), s. 83-101.

Kacprzak E., Staszewska S., 2008, Rozwój obszarów mieszkaniowych w strefie podmiejskiej miasta Poznania, [w:] A. Jezierska-Thöle, L. Kozłowski (red.), Gospodarka przestrzenna w strefie kontinuum miejsko-wiejskiego w Polsce, Wydawnictwo Naukowe Uniwersytetu Mikołaja Kopernika, Toruń, s. 127-144.

Kłodziński M., 1996, Wielofunkcyjny rozwój terenów wiejskich w Polsce i w krajach Unii Europejskiej, Wydawnictwo SGGW, Warszawa.

Kołodziejczak A., 2008, Zróżnicowanie rozwoju społeczno-gospodarczego strefy podmiejskiej Poznania, Studia Obszarów Wiejskich, 13, s. 49-58.

Kołodziejczak A., 2016, Rolnictwo czy węgiel brunatny - utylitarność zasobów w rozwoju lokalnym gminy Krobi, Studia Obszarów Wiejskich, 44, s. 125-136.

Koncepcja Kierunków Rozwoju Przestrzennego Metropolii Poznań, 2014.

Kostrowicki J., 1976. Obszary wiejskie jako przestrzeń wielofunkcyjna. Zagadnienia badawcze i planistyczne, Przegląd Geograficzny, 48, 4, s. 601-611.

Krzyżaniak J., 2012, Dobre praktyki zagospodarowania przestrzeni wiejskiej na przykładzie laureatów konkursu „Przyjazna wieś", Studia Obszarów Wiejskich, 29, s. 247-262.

Liszewski S., 1985, Użytkowanie ziemi jako kryterium strefy podmiejskiej, Acta Universitatis Lodziensis, Folia Geographica, 5, s. 75-90.

Parysek J., 2001, Gospodarka lokalna, Wydawnictwo Naukowe UAM, Poznań.

Parysek J., 2006, Wprowadzenie do gospodarki przestrzennej. Wybrane aspekty praktyczne, Wydawnictwo Naukowe UAM, Poznań.

Parysek J., 2008, Aglomeracje miejskie w Polsce oraz problemy ich funkcjonowania i rozwoju Seria Rozwój Regionalny i Polityka Regionalna, 5, s. 29-48.

Plan Zagospodarowania Przestrzennego Województwa Wielkopolskiego, 2010, Samorząd Województwa Wielkopolskiego, Poznań.

Raport z konsultacji społecznych na temat kierunków zagospodarowania przestrzennego centrum miejscowości Rokietnica, 2016, Centrum Badań Metropolitalnych, Poznań.

Rokickie Wiadomości. Czasopismo Gminy Rokietnica, 2015, 11 (196), s. 10-11.

Rosner A., 2001, Społeczno-ekonomiczne uwarunkowania przemian strukturalnych w rolnictwie [w:] I. Bukraba-Rylska, A. Rosner (red.), Wieś i rolnictwo na przełomie wieków, IRWiR PAN, Warszawa, s. 47-61.

Rosner A., 2012, Zmiany rozkładu przestrzennego zaludnienia obszarów wiejskich. Wiejskie obszary zmniejszajqqce zaludnienie i koncentrujqce ludność wiejskq, IRWiR PAN, Warszawa.

Rural Developments, 1997, CAP 2000, Working Document, European Commission.

Sokołowski D., 2005, Wybrane metody weryfikacji wskaźników urbanizacji i kryteriów miejskości, [w:] I. Jażdżewska (red.) Współczesne procesy urbanizacji i ich skutki, XVIII Konserwatorium wiedzy o mieście, Łódź, s. 75-90.

Staszewska S., 2008, Strefa podmiejska konkurencja dla miasta? [w:] J. Słodczyk, M. Śmigielska (red.), Współczesne kierunki i wymiary procesów urbanizacji, Wydawnictwo Uniwersytetu Opolskiego, Opole, s. 323-331. 
Staszewska S., 2009, Bariery rozwoju przymiejskich obszarów wiejskich, Studia Obszarów Wiejskich, 17 , s. $175-186$.

Staszewska S., 2013, Urbanizacja przestrzenna strefy podmiejskiej polskiego miasta, Bogucki Wydawnictwo Naukowe, Poznań.

Strategia Rozwoju Aglomeracji Poznańskiej. Metropolia Poznań 2020, 2013, Centrum Badań Metropolitalnych, Poznań.

Studium uwarunkowań rozwoju przestrzennego aglomeracji poznańskiej, 2013, Centrum Badań Metropolitalnych, Poznań.

Studium Uwarunkowań i Kierunków Zagospodarowania Przestrzennego Gminy Rokietnica, 2011 (wraz ze zmianą z 2016 r.), Biuro Projektowe Armageddon, Poznań.

Ustawa z dnia 27.03.2003 r. o planowaniu i zagospodarowaniu przestrzennym (Dz. U. 2015 poz. 199, ze zmianami).

Wójcik M., 2011, Współczesne kierunki i podejścia badawcze w geografii wsi, Przegląd Geograficzny, 83, 2, s. 163-185.

Wielowariantowa analiza i symulacja zagospodarowania przestrzennego centrum Rokietnicy, 2015, Biuro Projektowe Armageddon, Poznań.

Idziak W., Wilczyński R., 2013, Odnowa wsi. Przestrzeń. Ludzie. Działania, Krajowa Sieć Obszarów Wiejskich, Fundacja Programów Pomocy dla Rolnictwa FAPA, Warszawa.

Wilkin J., 2007, Obszary wiejskie w warunkach dynamizacji zmian strukturalnych, [w:] Ekspertyzy do Strategii Rozwoju Społeczno-Gospodarczego Polski Wschodniej do 2020 r., t. I., Ministerstwo Rozwoju Regionalnego, Warszawa, s. 593-616.

www.stat.gov.pl - Bank Danych Lokalnych.

www.rokietnica.pl

www.e-rokietnica.pl

\section{Summary}

The aim of the paper is to underline the importance of land as a local resource in rural area development, particularly in the context of land management and policy. The identification and characteristics of planning conditions and planning process cycle for the new centre of Rokietnica - an administrative and economic hub of the rural commune in the district of Poznań, have allowed to show the complexity and importance of the strategic approach to space management in rural areas if the suburban area. The analysis of the new space planning process for the village has allowed to present the project implementation objectives as well as the contributory factors and barriers encountered during the project implementation. Simultaneously, the paper identifies good practices in local resource management and in spatial policies of the rural commune.

The Rokietnica based study was induced by a specific location of the commune and by the related change of the village character and intentional comprehensive approach of the self-government authorities to the spatial planning. It is worth mentioning the extensive cooperation involving the inhabitants, local authorities, representatives of the scientific community and urban planners/architects during the development of spatial planning concept. Also, the application of innovative techniques of public consultations, presentation of design criteria, scale of undertaking and its conditions are noteworthy. 